Cosmin BORZA

Sextil Puşcariu Institute of Linguistics and Literary History Cluj-Napoca, Romania cosmi_borza@yahoo.com

\title{
THE HEROINES. RE-MYTHICIZATION OF THE FIRST WORLD WAR IN THE ROMANIAN LITERATURE
}

Recommended Citation: Borza, Cosmin. "The Heroines. Re-mythicization of the First World War in the Romanian Literature.” Metacritic Journal for Comparative Studies and Theory 5.1 (2019): https://doi.org/10.24193/mjcst.2019.7.06

Abstract: The paper analyses the most significant Romanian literary representation of First World War in which femininity is imagined as subversive to the "negative myth" of the conflagration. In the Romanian culture, this so-called "negative myth" is of such great magnitude that the literary works that anathemize the historical event responsible for the birth of Greater Romania are labelled as attacks on the nation. A discordant note to the above mentioned demythologizing tendency is struck by a series of female characters from novels signed especially by "classical" writers such as Hortensia Papadat-Bengescu, Camil Petrescu, Liviu Rebreanu, and Ion Agârbiceanu. These sui-generis "heroines" propagate an image of femininity capable of giving stability and hope to a world/nation devastated by male vanities and vulnerabilities. Thus, they postulate a subversive discourse in relation both to the heroic-patriotic imagery of propaganda, and to the "negative myth" of the war consecrated by most Romanian writers.

Keywords: First World War, Romanian literature, female characters, de/remythicization, Hortensia Papadat-Bengescu

The cultural myth of the First World War continues to be a deeply negative one. As shown - with equally thorough and convincing arguments - by Samuel Hynes in his 1990 study A War Imagined, the "Great War" was, for artists, one of the greatest lies/scams of the modern age, since its senseless battles "slaughtered" a generation of naïve young men, their heads full of abstractions such as homeland, glory, heroism, honor, salvation of the human kind or safeguarding the democracy. Subsequently, 
when dealing with the conflagration, the writers who are not in line with the propaganda encounter disillusion, shock, anger, i.e. an obvious penchant for demythicization.

\section{The Negative Myth of the War}

Even if Hynes refers to the English space, the literature disavowing the war, which entails the disclosure of its cruelty and absurdity, is considerably spread also in the other Western countries, by some of its most prestigious representatives - from Henri Barbusse, Under Fire (1916) and Georges Duhamel, The New Book of Martyrs (1917), to Erich Maria Remarque, All Quiet on the Western Front (1929), to Ernest Hemingway, A Farewell to Arms (1929), and to Arnold Zweig, Outside Verdun (1935) -, but it also characterizes most of the literary cultures of Eastern Europe (Cornis-Pope and Neubauer 177-191).

Even in the Romanian literature, where the First World War is associated with the creation of Greater Romania (in the 1918 Union of all the historic Romanian regions), this negative myth is so significantly spread that it comes to be considered a matter of national importance, a symbolic attempt on the nation. In 1929, historian Constantin Kirițescu, author of the first Romanian history of the First World War, and Ion Agârbiceanu, one of the most reputed Romanian prose writers of the beginning of the $20^{\text {th }}$ century, criticized very harshly the way in which our writers related to the event that had generated the country's "coalescence":

Isn't it a crime against this nation, against the past, against the dead ones, to disregard everything that once was greatness, pain, sanctity, and to reopen solely the sores of indignity and filth?' (Kirițescu 51).

Why should the post-union generations be acquainted first, via literature, solely with the passions of some lecherous man, with the traffic of war profiteers, with the scum of a society, with those who helped themselves to the soldiers' bread? The sacrifice accepted with enduring Romanian patience, on the front and behind it, the acts of heroism, the wisdom of the soldier who managed to escape bolshevism, the boundless

1 "Nu este o crimă împotriva acestei națiuni, împotriva trecutului, împotriva morților neamului, a trece cu vederea tot ce a fost mărire, durere, sfințenie, spre a nu răscoli decât josnicia și murdăria?” (My translation). 
sorrow of the invaded Country, and so on and so forth - why couldn't they be beheld by the eyes of the reader in the literary creation?² (Agârbiceanu, Literatura 715).

Their targets are the novels that de-mythicize overtly the heroizing image of the war offered by the historians or propagandistic writings of the time, while proposing in exchange simple "frescoes" of cowardice, corruption, egoism and demagogy: $\hat{I} n$ cetatea idealului (In the City of the Ideal, 1920) by Dem. Theodorescu, Strada Lăpuşneanu (Lăpuşneanu Street, 1921) by Mihail Sadoveanu, Roșu, galben și albastru (Red, Yellow, and Blue, 1924) by Ion Minulescu, Hârdăul lui Satan (Satan's Pot, 1925) by Eugen Todie, and Intunecare (Gathering Clouds, 1928) by Cezar Petrescu. With such writings, say both Kirițescu and Agârbiceanu, "literature takes down that which school builds," becoming an anti-national force that should be urgently refuted.

In fact, war de-mythicizing literature is much broader in Romania than it is suggested by the five literary examples above. The disparagement of the patrioteered patterns of perception of the conflagration continued to be an almost manifest purpose both for the two of the inter-war novels that became classics, i.e. Liviu Rebreanu's Pădurea spânzuraților (Forest of the Hanged, 1922) and Camil Petrescu's Ultima noapte de dragoste, întâia noapte de război (Last Night of Love, First Night of War, 1930), and for a long series of writers of lower literary importance: Ioan Dragu, Moartea albă (White Death, 1918), V. Demetrius, Domnul colonel (Colonel, 1920) and Vieți zdrobite (Shattered Lives, 1926), F. Aderca, Moartea unei republici roșii (The Death of a Red Republic, 1924) and 1916 (1936), George Cornea, Nebunia lumii (The World's Frenzy, 1924), Șt. Zeletin, Retragerea (The Fallback, 1926), Vasile Savel, Vadul hoților (The Thieves' Crossing, 1926), Gh. Brăescu, Moș Belea (Old Man Trouble, 1927), Sebastian Bornemisa, Duhul cel rău (The Evil Spirit, 1926), G. Vlădescu-Albești, Simon (1928), D. Barnoschi, Mărturisirea trupului (The Body's Confession, 1930), Alexandru Rădulescu, Bătea un vânt de nebunie (A Wind of Madness Blew, 1932), Dimitrie Stănculescu, Ispăşire (Atonement, 1932), Gabriel Drăgan, Pe frontul Mărășești învie morții... (Dead Come

2 "Pentru ce generațiile de după unire să facă cunoștință mai întâi, prin mijlocirea literaturii, numai cu patimile cutărui libidinos, cu traficul îmbogățiţilor de răsboiu, cu drojdia unei societăți, cu cei ce-au șterpelit din hrana soldatului? Mucenicia purtată cu îndelungă răbdarea românească, pe front și la spatele frontului, actele de eroism, cumințenia soldatului nebolșevizat de ruși, marea durere a Țării invadate etc. etc. - pentru ce nu ar putea fi pusă subt ochii cetitorului în creația literară?” (My translation). 
to Life on the Mărășești Battle Front, 1934), George M. Vlădescu, Moartea fratelui meu (My Brother's Death, 1934), Grigore Brădișteanu, Zidul plângerilor (The Wall of Wailings, 1935), M. Câmpeanu, Casa de întâlniri (The Meeting House, 1935), Remus Dumitrașcu, Gheare (Claws, 1935) etc. And the list could go on with the realistsocialist works of the 1950s-1960s, which projected the "Great War" as a bloodshed orchestrated by the "bourgeois-landlord classes" (Istrate et al.).

It seems that nothing escaped the critical or even satirical perspective: the Great Union did not depend at all on the actions of the Romanian army that had been defeated catastrophically in 1916, after only two weeks, Bucharest, the capital city, being surrendered without a fight; the hero of the grand victories of Mărăști and Oituz, for the defense of Moldavia, where the country's leadership retreated, general Alexandru Averescu, lost almost any trace of mythological aura once he became actively engaged in politics; Romania was among the belligerents who had suffered the largest number of victims; after the Union, the economic crisis struck the new country, and the legislative reforms (universal manhood suffrage and the apportionment of property to all the peasants) did not lift at all the standard of living of most of the populations, and we could go on with such examples.

\section{Women's War}

Nevertheless, against the backdrop of its quasi-generalized disparagement, the First World War brought about in the Romanian culture a fundamental shift in the representation of women/femininity, which, reversely, since it did not pursue propaganda, nationalist thesis, often generated a subtle re-mythicizing of war itself. Despite the fact that neither in Romania, nor in the rest of the world3, did the 19141918 conflagration prompt any actual improvement of the woman's condition in society, or cancel the hegemony of manhood, feminine voices, faces and actions started to matter as much as and even more than the men's. Instead of a passive positioning, behind and far from the front's theater of operations, the woman became a protagonist of war, re-semanticizing its purposes.

\footnotetext{
3 “'Historians had to acknowledge that women's war efforts did not cause a profound change of the hegemonic gender order or long-term improvements of the status of women, even though they might have been of great importance for the contemporaries themselves. Also, dichotomous and hierarchically constructed concepts of femininity and masculinity prevailed in the public sphere of the 'home front' and the theatres of war, where women faced being denounced and sexualized. These insights led historians to believe that the war did not, in fact, have any long-term implications on political gender transformations" (Bader-Zaar, Hämmerle and Überegger 3). 
A captivating synthesis of the said metamorphosis of the social-cultural imaginary is offered by Alin Ciupală in his study of 2017 - Bătălia lor. Femeile din România în Primul Război Mondial (Their Battle. Romanian Women in the First World War). In this volume, solid chapters are dedicated to the two symbols of war in Romania, against whose myth none of the "great men" of the age can compete: from King Ferdinand I to the president of the Council of Ministers Ion I. C. Brătianu, and to the generals Alexandru Averescu, Eremia Grigorescu or Constantin Prezan. These were Ecaterina Teodoroiu, "the virgin martyr," "Romania's Joan of Arc," and Queen Maria, "the empress of all Romanians" (the name wounded soldiers she would visit in the military hospitals had given her). Even if Ecaterina Teodoroiu had been 22 years old, not 19, and had infiltrated the front only to be near her brother, and not because of some patriotic impulse, and even if the Queen had been involved in numerous extramarital affairs, had had illegitimate children and had orchestrated the most cynical political plots, their myth continues to be almost intact to this day, being decisively instrumental in the justification, in the collective consciousness, of Romania's participation in the First World War.

Moreover, Ciupală reports on the role of the nurses who had come from among the social elite and had contributed to the achievement of an authentic communion of the social classes, something that once had never even been dreamt of. The mutual respect between the peasant-soldiers and the Red Cross nurses, most of them the offspring of boyar or bourgeois families, was a leitmotif of the entries in many of the feminine diaries published after the War. Last, but definitely not least, the same diary entries strengthen the idea that - in Romania, too - the First World War included an aspect called by most of researchers a "battle of the sexes" (Gilbert; Jenson, Michel and Collins Weitz; Nolan), i.e. an unparalleled acute awareness of the women's public role, of their capacity to sit in active offices left vacant by the men trapped in the trenches.

For a suggestive example of the many possible ones, Yvonne Blondel's confession needs to be read:

Before this tempest, I would think my life was interesting and put to good use, with its whole measure of variety, resplendent niceties, theater plays, horse racing, some charity work, friendly chatter and all the gestures of a woman of the world in her environment. Now, after I've lived these intense hours, all spun from work and devotion, so soulful 
they could overflow, I would find it absolutely impossible for now to resume my gilded burden and to stay inactive in my comfortable abode (Blondel 37).

Thus, the post-war demobilization of the traumatized and disillusioned men is matched by an unprecedented mobilization of the women.

\section{Romanian "Heroines"}

It is precisely the abandonment of this only rarely "gilded burden" of inertia and marginalization that is delivered by most of the feminine characters in the significant Romanian novels approaching the First World War.

I would begin with Ion Agârbiceanu himself, whom I quoted earlier when he lamented the literature's lack of contribution to the rehabilitation of the heroism and patriotism of participating in the war. Seeking to rectify the Romanian culture's said shortcoming, the prose writer imagines not at all accidentally a heroine on the road to the awakening of both the woman's self-awareness and the patriotic-national conscience. In Țară şi neam (Country and People) of 1928, subtitled Insemnările unei logodnice (Notes of a Fiancée), protagonist Maria Neagu first appears in a condition dependent on the man. Since the war separates her from her fiancé just one week before the wedding, the young woman relates egotistically to the event, asking her suitor to desert: "Your will is the servant of duty. The homeland does not forgive you when you leave her in times of distress! If these are your words, then everything is over for me! [...] Oh, no! I can't believe you've cheated on me, that you can love someone else more than you love me"5 (Agârbiceanu, Țară 24). Later, in the wake of her harsh experience as a nurse, the woman understands her individuality and, thus, the meaning of the collective sacrifice. Despite the tragic end (the fiancé dies on the front and she falls ill with exanthematous typhus), her last notes are to the other nurses who should learn from the suffering they experienced in the years of war that their role is not second to the men's, that new life springs after the conflagration, a life in which the woman should accept her condition of society protagonist: "And in

4 "Înaintea aceste vijelii, găseam viaţa mea interesantă și bine folosită, cu întreaga sa doză de varietate, mondenități din belşug, teatre, curse de cai, puțină operă de caritate, taifasuri amicale şi toate gesturile unei femei de lume în mediul său. Acum, după ce am trăit aceste ore fierbinți, țesute toate din muncă și devotament, pline de suflet mai să dea pe-afară, mi-ar fi absolut imposibil deocamdată să reiau jugul aurit și să rămân inactivă în locuința mea confortabilă” (My translation).

5 "Voința ta e roaba datoriei. Patria nu-ți iartă s-o părăsești în vreme de primejdie! Dacă sunt cuvintele tale acestea, atunci pentru mine totul s-a sfârșit! [...] O, nu! Nu pot crede că m-ai înșelat, că poți iubi pe cineva mai mult decât pe mine" (My translation). 
particular do not forget what those bitter days have taught you: love is not whole and does not make anyone happy unless it serves God, the People, your neighbour and yourself at the same time"6 (Agârbiceanu, Țară 190).

Lacking Agârbiceanu's moralizing thesis but having almost the same tendency to outline the revelatory impact of the war, Liviu Rebreanu, in The Forest of the Hanged, creates one of the most memorable female characters in Romanian literature: the Hungarian countrywoman Ilona. While the male protagonists of the novel fall victims to patriotic, nationalistic and/or religious abstractions amplified to paroxysm, and come to betray their most intimate beliefs, their families, childhood friends etc., the artlessness of Ilona's behaviour, able to regenerate human values, is revealed even more perceptibly in these times when the whole life is unsettled, and the identity-related simulacra are exposed swiftly. Not by chance, when the novel The Forest of the Hanged was adapted for the screen, the director Liviu Ciulei (who received an award at Cannes in 1965) offered Ilona an even more significant exposure than Rebreanu did, with the ending scene of the film (which is considered the most valuable, aesthetically speaking, in the whole history of Romanian filmmaking) closing up on her simple and extremely scarce gestures and words, her austere clothing, angelic face that becomes suddenly and blindingly illuminated, become abstract, symbolizing the capacity of the natural to revitalize spiritually a world levelled by too many conventions.

Likewise, Camil Petrescu - in, undoubtedly, the best known and most influential Romanian novel wherein the mythicizing templates about the first world conflagration are deconstructed, Last Night of Love, First Night of War - brings in a female character to show how war destabilizes even the steadiest preconceptions. By transposing in his prose a real, historically documented character7, the young Maria Manciulea, whose name he actually keeps, Camil Petrescu reiterates the collapse of the domestic army, but also the revelation of the naturalness with which, in critical situations, the simple man sacrifices himself, and becomes a true hero. In the chapter Întâmplări pe apa Oltului, just because they were "pretty," kind of "fun-loving" and had also been courted by the Hungarian officers, two young women in a village near to the front, sisters Maria and Ana, are considered "spies". The most rudely

6 "Și mai ales nu uitați ceea ce ați învățat în zile amare: iubirea nu-i deplină și nu face pe nimeni fericit decât slujind în aceeași vreme lui Dumnezeu, Neamului, de-aproapelui și ție însăți” (My translation).

7 See Lucian Ionescu-Tomșani, Eroina de la Olt: Maria Manciulea (The Heroine from Olt: Maria Manciulea), for a detailed biography. 
misogynistic preconceptions decide on their humiliation and apprehension, and even on their absurd conviction to death, yet, in the end, Maria herself, being a local woman who knew well the geography of the front, guides the crossing of the Olt river through shallows only known to her and, thus, they escape from the surrounding enemies.

But, in Romanian literature, the most significant - owing to its complexity representation of femininity in relation to war comes from Hortensia Papadat-Bengescu and it is shaped in the novel Balaurul (The Dragon), published in 1923, which is an expansion of the author's war diary dating back to 1916 . Here, the undermining of the commonplaces of war literature involves the critical confrontation with both the pseudo-patriotism of propaganda writings, and the cliché regarding the charity/medical nurse (the typical representation of the woman participating in the conflagration). As proven by Alison S. Fell in the study Remembering French and British First World War Heroines, an interpretation which is, in fact, valid also in the Romanian cultural sphere, women's confessions about the war project the "perfect heroine" in the charity nurse, owing to the fact that she reconciles without any tension the women's aspiration to action and involvement and the sensible assumption of a role clearly delineated by men: "Nursing allowed women to be close to the front while remaining firmly situated within traditional understandings of the feminized domestic sphere" (Fell 108). On the contrary, in Hortensia Papadat-Bengescu's novel, Laura/Laurenția is from the beginning subversive in relation to any patriotic, mobilizing, sacrificial role of the charity nurse. The country's involvement in the war is passed through a bovaristic filter, being evaluated as an antidote to a flat, disappointing, smothering existence ("life as a blank page", "colossal deficit of existence"):

War! The word earned a meaning. The terror of it was some kind of joy for her. On the eve of war, Laura had had conflicts with life, in which she had been defeated, she had abandoned, but the conflicts had not been solved in her unruly soul, nor had they been solved in her rebellious existence. War brought a solution to these conflicts. A solution matching her revolts. It seemed like her struggle, which sought and could not find a 
conclusion had wakened for her specific pain and need the colossal storm, the power of which would dissolve any other powers"8 (Papadat-Bengescu 182-183).

In relation to the "petty chores," to the "struggles" and "reckoning," the war seems to be an "elementary force unleashed toward destruction and creation" (Papadat-Bengescu 185). This is how the woman's revolt is justified when the Red Cross president asks her to take a break from caring for the wounded:

She should be the one to give it up! She might have even smiled. She who, out of them all, had the passion of sacrifice, the need of it, who now lived toiling like this as if such toil were her nutriment. It was her for whom everything that would come came. She, for whom the red flag had been unfolded! The war had started for her, to change the meaning of things and, with this meaning, in which her bad and hateful predicament was embedded, to rip her predicament out of its evil roots ${ }^{9}$ (Papadat-Bengescu 215).

Of course, not much time would pass and the "distress" meant to heal "the humankind's moral disease," the "hurricane" that "shatters the trash fouled by the world's vices" (Papadat-Bengescu 215) would create increasingly worse disappointment. In chapters with titles that are more than manifest Omul către om, fiară (Man to man, beast), Iadul (Hell), Omul căruia i se vede inima (The man with the heart at sight), Dihorul (The ferret), Temnița (The dungeon), In întuneric (The darkness), Laura becomes the lucid reflector of the horrors of war: parents who throw their dead child from the train, to save those still alive, soldiers hacked in some of the most surrealistic ways, the orderly who accepts all the humiliations from the wounded officer not on account of devotion, but to ensure his distance from the front, the priest who offers his daughter to the German occupier, because she had had a child from a relationship with a Romanian soldier, which the family had not wanted, and so on and so forth.

8 "Război! Cuvântul căpăta un înțeles. Spaima lui era un fel de bucurie pentru ea. În ajun Laura avea cu viața conflicte în care fusese învinsă, abdicase, dar care nu se rezolvaseră în sufletul ei revoltat, nici în existența ei răzvrătită. Acestor conflicte războiul le aducea o soluție. Una uriaşă, proporționată cu revoltele ei. Părea că zbuciumul ei, care căuta și nu găsea rezolvare, iscase pentru durerea şi nevoia ei anume vijelia colosală, în a cărei putere aveau să se dizolve orice alte puteri” (My translation).

9 "Ea să renunțe! Ar fi putut chiar surâde. Ea, care dintre toate avea patima sacrificiului, nevoia lui, care acum trăia din truda asta ca dintr-o hrană. Ea! Pentru care se pregătea tot ce se pregătea. Ea, pentru care se desfășurase peste lume faldul stindardului roșu! Pentru ea izbucnise războiul, ca să schimbe rostul lucrurilor și, odată cu acest rost, în care necazul ei rău şi duşmănos era încrustat, să-și smulgă necazul din rădăcinile lui rele" (My translation). 
Nevertheless, unlike masculine prose writing approaching the trauma of the participation in the war and, thus, the crisis triggered by the shattering of the initial illusions, Hortensia Papadat-Bengescu's The Dragon does not progress to a denouement of confusion and dissuasion. Since she does not really believe in vain abstractions like "Homeland" and "Ideal," Laura does not linger too long in the state of "lassitude" generated by the "agitation of those terrible times" (Papadat-Bengescu 385). She seeks a higher humanistic significance of war and she finds it - beyond any cynicism or egoism - in the regenerating force of gruesome experiences:

Laura truly believed that the laws of blood and not the will of men make wars, but in the tumble of the flow, the blood is sifted. [...] Laura was like the blade of grass rediscovering tenderness and, equally delicate, she felt as if she had to live and wait for life. She knew she would welcome joy just like she welcomed pain, with passion and wonder ${ }^{10}$ (Papadat-Bengescu 392, 396).

Surviving the war, the woman painted by Hortensia Papadat-Bengescu is convinced she earned a vital energy which neither Bovarysms, nor the roles pre-established by the old patriarchal world "of peace" can steal.

\section{Conclusion}

Without substituting themselves explicitly for "mobilizing Minervas" discrediting the men's role of "protectors" - a metaphor used by Kimberly Jensen in a 2008 study on the participation of American women in the First World War -, Ion Agârbiceanu's Maria, Rebreanu's Ilona, Camil Petrescu's Maria and, especially, Hortensia PapadatBengescu's Laura destabilize the negative myth of war. Certainly, these characters do not restore the heroic-patriotic imaginary, but they circulate an image of vigorous femininity, able to ensure stability and hope to a world devastated by masculine vanities and vulnerabilities.

10 "Laura, în adevăr, credea că legile sângelui, iar nu vrerile oamenilor, fac războaiele, dar în vălmășagul scurgerii, sângele se alege. [...] Laura era ca firul de iarbă care dă din nou fraged și, plăpândă ca și el, simțea că trebuie să trăiască și să aștepte viața. Știa că va primi bucuria, cum primise și durerea, cu patimă și uimire" (My translation). 


\section{References:}

Agârbiceanu, I. (Ion Turcu). "Literatura de răsboiu” ("War Literature”). Transilvania 9, 1929: 715 .

Agârbiceanu, I. Țară și Neam. Însemnările unei logodnice (Country and People. Notes of a Fiancée). Editura Casei Școalelor, 1928.

Bader-Zaar, Birgitta, et al., Gender and the First World War. Palgrave Macmillan, 2014.

Blondel, Yvonne. Jurnal de război 1916-1917. Frontul de sud al României. Romanian version by Rodica Zagăr, Romanian Cultural Institute, 2005.

Ciupală, Alin. Bătălia lor. Femeile din România în Primul Război Mondial (Their Battle. Romanian Women in the First World War). Polirom, 2017.

Cornis-Pope, Marcel, and John Neubauer, editors. History of the Literary Cultures of EastCentral Europe: Junctures and Disjunctures in the 19th and 2oth Centuries, vol. I. John Benjamins Publishing Company, 2004.

Fell, Alison S. "Remembering French and British First World War Heroines." Gender and the First World War. Edited by Birgitta Bader-Zaar, et al., Palgrave Macmillan, 2014: 108-126.

Gilbert, Sandra M. "Soldier's Heart: Literary men, Literary Women and the Great War." Signs 8.3, 1983: 422-450.

Hynes, Samuel. A War Imagined: The First World War and English Culture. Bodley Head, 1990.

Ionescu-Tomșani, Lucian. Eroina de la Olt: Maria Manciulea (The Heroine from Olt: Maria Manciulea). Editura Militară, 1979.

Istrate, Ion, et al. Dicționarul romanului românesc de la origini până la 1989 (Chronological Dictionary of the Romanian Novel, from Its Origins to 1989). Editura Academiei Române, 2004.

Jensen, Kimberly. Mobilizing Minerva. American Women in the First World War. University of Illinois Press, 2008.

Jenson, Jane, et al., (eds). Behind the Lines: Gender and the Two World Wars. Yale UP, 1987.

Kirițescu, Constantin. Literatura împotriva educației? Generația războiului de întregire și scriitorii noștri (Literature against Education? The Generation of the War of Union and Our Writers). Cartea Românească,1929.

Nolan, Elizabeth. "American Women Writers and the First World War.” Literature Compass 4.3, 2007: 525-538.

Papadat-Bengescu, Hortensia. Balaurul (The Dragon), in Opere, I. Romane (Works. I. Novels). Edition coordinated by Gabriela Omăt, text edited by Eugenia Tudor Anton, notes 
and comments by Eugenia Tudor Anton and Gabriela Omăt, introductory study by Eugen Simion. Romanian Academy, Fundația Națională pentru Știință și Artă, 2012.

Petrescu, Camil. Ultima noapte de dragoste, întâia noapte de război (Last Night of Love, First Night of War). Cultura Națională, 1930.

Rebreanu, Liviu. Pădurea spanzuraților. Cartea Românească, 1922. Translated by A.V. Wise as Forest of the Hanged. Duffield, 1930. 